Discussion Paper No. 05-22

Knowledge Flows and R\&D Co-operation: Firm-level Evidence from Germany

Tobias Schmidt

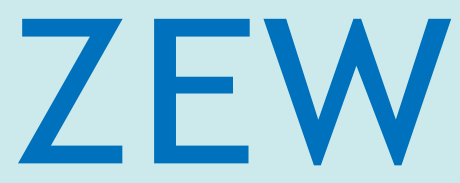

Zentrum für Europäische Wirtschaftsforschung $\mathrm{GmbH}$

Centre for European

Economic Research 
Discussion Paper No. 05-22

\title{
Knowledge Flows and R\&D Co-operation: Firm-level Evidence from Germany
}

\author{
Tobias Schmidt
}

Download this ZEW Discussion Paper from our ftp server:

\author{
ftp://ftp.zew.de/pub/zew-docs/dp/dp0522.pdf
}

Die Discussion Papers dienen einer möglichst schnellen Verbreitung von neueren Forschungsarbeiten des ZEW. Die Beiträge liegen in alleiniger Verantwortung der Autoren und stellen nicht notwendigerweise die Meinung des ZEW dar.

Discussion Papers are intended to make results of ZEW research promptly available to other economists in order to encourage discussion and suggestions for revisions. The authors are solely responsible for the contents which do not necessarily represent the opinion of the ZEW. 


\section{Non-technical summary}

Knowledge is an essential input for firms' innovation processes. The increased complexity of such processes and of new technologies leads firms to look for valuable knowledge externally to complement their own knowledge and skills. This is one reason for the current surge in external knowledge-sourcing. However, not only the demand for external knowledge has increased - its supply is also (potentially) higher. The advent of ICT has made it much easier for firms to gain access to external knowledge and to codify, distribute and use this knowledge. Then again, since firm-specific knowledge is an important determinant of competitive advantage, firms intensify their efforts to protect their knowledge against external access and in doing so limit the supply of freely available information. It has been argued that one way to achieve both a high level of knowledge flow into a firm and sufficiently protect internal knowledge from leaking out is to cooperate in R\&D.

In this paper we investigate the determinants of firms' R\&D co-operation decisions in general, focusing in particular on the role of incoming and outgoing knowledge spillovers. To enhance our analysis we not only investigate the decision of firms to cooperate in general, but also analyse firms' decisions to cooperate with research institutes and suppliers/customers.

Using firm-level data from the Third Community Innovation Survey (CIS III) for Germany, we find that knowledge flows matter for the R\&D co-operation decisions of firms. In particular outgoing spillovers (or rather their prevention through appropriability mechanisms) have a significant influence on the propensity to cooperate in innovation projects. While formal protection methods, like patents, negatively influence the probability to cooperate, strategic protection methods (e.g. secrecy, lead-time advantages) have a positive impact. Comparing our results with those of similar studies in Belgium and Spain, we find that most results are in line with those found for the other countries. However, the strong negative influence of legal protection on the probability to co-operate in $R \& D$ seems to be a unique feature of Germany. 
Analysing according to type of co-operation partner shows that there is a difference of motives, especially with regard to risk-sharing and absorptive capacity, for co-operating with specific partners. The results also suggest that firms' decisions to cooperate with specific partners are not independent of one another. 


\title{
Knowledge Flows and R\&D Co-operation: Firm-level Evidence from Germany
}

\author{
Tobias Schmidt ${ }^{1}$
}

\begin{abstract}
This paper analyzes the determinants of R\&D co-operation among German manufacturing firms. Using firm level data from the Third Community Innovation Survey from Germany, we focus on the role of spillovers in explaining R\&D cooperation. We also investigate firms' decisions to cooperate with research institutions or with suppliers and customers. Implementing a two-step estimation procedure, we find a positive effect of knowledge flows on the probability of R\&D co-operation in most model specifications. Additionally, we show that firms with high intramural $R \& D$ budgets are more likely to cooperate with universities and research institutions than with suppliers and customers.
\end{abstract}

Keywords: Spillovers, R\&D Co-operation, CIS 3

JEL Codes: O31, O32, L22

Acknowledgements: The author would like to thank Prof. Dr. Uwe Cantner, Dr. Georg Licht, Dr. Christian Rammer, Wolfgang Sofka, Bettina Peters, Tyler Schaffner and the participants of the following meetings for their valuable comments: 4th IEEF meeting, Druid Summer Conference 2004, CESIS Conference 2004 and EUNIP Conference 2004.

${ }^{1}$ Center for European Economic Research (ZEW), Department of Industrial Economics and International Management, P.O. Box 1034 43, D-68034 Mannheim, Germany, schmidt@zew.de 


\section{Introduction}

Knowledge is an essential input for firms' innovation processes. The increased complexity of such processes and of new technologies leads firms to look for valuable knowledge outside their own boundaries to complement their own knowledge and skills. This is one reason for the current surge in external knowledge sourcing. However, not only the demand for external knowledge has increased - its supply is also (potentially) higher. The advent of ICT has made it much easier for firms to gain access to external knowledge and to codify, distribute and use this knowledge. Then again, since firm-specific knowledge is an important determinant of competitive advantage, firms intensify their efforts to protect their knowledge against external access and in doing so limit the supply of freely available information. This is one reason why appropriability mechanisms like patents, copyright protection and secrecy have become more important.

One way to achieve both a high level of knowledge flow into a firm and sufficiently protect internal knowledge from leaking out is to cooperate in $R \& D^{1}$. In cooperative R\&D agreements, partners can decide on how much knowledge is to be exchanged, thus determining directly the level of voluntary knowledge flow. The amount of knowledge that can be exchanged is, however, constrained by the technological proximity of the partners and their general ability to utilize external knowledge ("absorptive capacity"). Related theoretical and empirical analysis has shown that technological closeness and high absorptive capacity increase the flow of knowledge between partners and consequently raise the incentive to engage in R\&D co-operation. Additionally, the amount of knowledge exchanged is usually larger if firms co-operate than if they tap into each others knowledge pools without co-operating.

One recent contribution to this strain of literature is the paper by Cassiman and Veugelers (2002). They empirically investigate the role of knowledge and

1We use the term "R\&D co-operation" in this text because it has become the common term used to describe co-operation as it is surveyed in the community innovation surveys of Eurostat. Note however that the CIS III survey for Germany was asking for innovation cooperation, which is the broader concept. 
absorptive capacity in the R\&D co-operation decisions of Belgium firms, focusing on finding differences between the effect of knowledge flow into firms ("incoming spillovers") and that of outbound knowledge flow (and their prevention) on firms' decisions to enter into an R\&D co-operation. Indeed, they find different effects of incoming spillovers, measured by the importance of external knowledge available to each firm, and appropriability, measured by the importance of strategic protection methods for internal knowledge, on the probability of cooperation in $R \& D$ projects.

Their model was modified and applied to Spanish firms by Lopez (2004). He focuses in particular on the role of cost- and risk-sharing of innovation projects for the co-operation decision taking into account the endogeneity of these concepts. His results confirm the conclusions of Cassiman and Veugelers (2002) that spillovers and appropriability play an important part in influencing R\&D cooperation decisions.

The purpose of this paper is to shed more light on the relationship between knowledge flows and R\&D co-operation in the German manufacturing sector. In order to compare the results with those from Belgium and Spain, we estimate a model that is similar to the models used in these two studies. We deviate, however, by using a different measure of absorptive capacity -- intramural R\&D budgets -- instead of an indicator of permanent R\&D.

In the next section we describe the motives for R\&D co-operation mentioned in the relevant literature. In Section 3 we explain how the empirical model is set up. Section 4 contains a description of the data and gives details on the operationalisation of the core concepts. Finally, the results presented in Section 5 are followed by our conclusions in Section 6. 


\section{Motives for Co-operation from Related Literature}

Both the theoretical and empirical studies on firms' co-operation decisions have identified an array of motives for and determinants of co-operation (an extensive overview can be found in Caloghirou et al., 2003). These can be categorized into three main groups: motives related to knowledge, motives related to cost- and risk-sharing, and determinants related to firm characteristics. ${ }^{2}$

The first group of motives is related to firms' in- and outbound flows of knowledge. De Bondt \& Veugelers (1991) show that the level of incoming spillovers -- the knowledge a firm acquires from external sources - positively influences the attractiveness of R\&D co-operation.

The effect of outgoing spillovers on co-operation is more ambiguous. If a firm's ability to protect its internal knowledge (appropriability) is limited, resulting in larger (involuntary) outgoing spillovers, the incentive to cooperate increases; firms are able to control (read: restrict) the outflow of knowledge to competitors who are not involved in the co-operation through collaborative agreements. The scale of the incentive generated depends on the structure of the market in question. If these markets are characterized by perfect competition, the incentive to limit outflows of knowledge through co-operation should be weak, as a firm can only cooperate with a limited number of competitors: Limiting the outflow of knowledge can only be partially achieved. Contrarily, if a firm is the leader of an oligopoly, the incentive to use co-operation to limit spillovers to competitors should be greater; in this case most knowledge outflows can be controlled. A high level of outgoing spillovers may, however, also discourage involvement in $R \& D$ cooperations by increasing the incentive to free-ride on a partner's $R \& D$ investment, i.e., cheat within the cooperative agreement (see Kesteloot and Veugelers, 1994). In addition, outgoing spillovers motivate parties outside an

\footnotetext{
${ }^{2}$ Note, in this paper we only focus on one side of the cooperation, in the sense, that we do not take into account the "hampering factors" for cooperation. Firms might for example not be able to find an (adequate) partner for cooperating. This aspect was neglected here because the data available to us doesn't allow us to identify the exact partners participating in a co-operation. Because of that we can't analyse how the structure and set-up of the partners has influenced a firm's decision to engage in cooperative $\mathrm{R} \& \mathrm{D}$ or not.
} 
agreement to free-ride on the investments of R\&D partnerships (Greenlee and Cassiman, 1999). Both effects reduce the attractiveness of R\&D co-operations.

The notion that incoming and outgoing spillovers and appropriability have their own distinct effects on the probability to cooperate was tested by an empirical study by Cassiman and Veugelers (2002). They find a significant and positive effect of level of incoming spillovers and appropriability on probability of co-operation.

One other topic closely related to knowledge flow is "absorptive capacity". Cohen and Levinthal (1989) argue that absorptive capacities are necessary "to identify, assimilate, and exploit knowledge from the environment" (p. 569). A firm with high absorptive capacities should thus be able to access a larger amount of knowledge than a firm with lower such capacities. Consequently, the benefit of cooperating and, in doing so, gaining access to knowledge not available in the public domain will be higher for the former. Since absorptive capacities can, according to Cohen and Levinthal (1989), be built up by investing in inhouse R\&D, it is not surprising that empirical studies have found that the amount of internal $R \& D$ spending is closely linked to the co-operation decision (see Veugelers, 1997).

A second group of motives for $R \& D$ co-operation is related to resource constraints within a firm. Practically no firm has all the necessary knowledge, competencies, and financial means to undertake an innovation project on its own.

Hagedoorn (1993) finds that technological complementarities are one of the most important reasons for firms to cooperate in R\&D. If the need for knowledge and skills complementary to a firm's own knowledge can not be satisfied via the market (e.g. due to market imperfections), the firm's incentive to cooperate increases. Access to complementarities is not only a motive for co-operation in general, but in particular for R\&D co-operation as R\&D and innovation projects usually require a larger amount and more specific assets than other projects of the firm.

A lack of financial resources for innovation projects is another motive for $R \& D$ co-operation related to resource constraints. Sakakibara (1997) supports this view, identifying two basic motives for co-operation: cost-sharing and skill- 
sharing. She argues that firms try to reduce their own project costs by cooperating with external partners. Expensive projects usually also bear a high risk for the firms undertaking them. Thus, risk-sharing is also a reason why firms cooperate with external partners. The increasing complexity and cost of research projects further enhances the role of these motives. Tether (2000) found analyzing data from the second Community Innovation Survey (CIS II) that the growing complexity of technological innovations has indeed led to more cooperative behaviour in the UK.

Finally, the third group of determinants of R\&D co-operation lies within the structure of the firm and the industry in which it operates. There have been many studies investigating the role of firm size as a factor influencing the R\&D co-operation decision. Most authors conclude that the probability of cooperation increases with size (e.g., Röller et al. (2001)). As far as the industry of the firm is concerned, Dachs et al. (2004) argue that the industry structure, with respect to intensity of competition, technological intensity, and appropriability conditions of the respective industry influences a firm's $R \& D$ co-operation decision.

Few empirical models try to distinguish between different types of cooperation partners or investigate the motives for co-operation with one specific partner. However, their number has been increasing in recent years (Belderbos (2004); Fontana et al. (2003); Dachs et al. (2004); Veugelers and Cassiman (2003); Kaiser (2002)). Kaiser (2002), for example, uses a nested logit model to investigate the R\&D co-operation decision as a two-stage process: First, the firm decides whether to co-operate or not; in the second stage it chooses a cooperation partner. The results of the studies estimating separate equations for different $R \& D$ co-operation partners suggest that there are indeed different motives for co-operating with universities, competitors and suppliers or customers. 


\section{The Empirical Model}

The motives for R\&D co-operation proposed by the related literature are the starting point for our empirical analysis. We model the probability of a firm being engaged in at least one $R \& D$ co-operation depending on the motives presented in Figure 1. To be able to estimate the influence of these motives, we assign one or more specific empirical measures (variables) to each motive. The expected direction of the impact of the motives for co-operation is (as well as the motives themselves) derived from the literature.

Figure 1: Factors influencing a firm's decision to have at least one R\&D cooperation with external partners in the empirical model

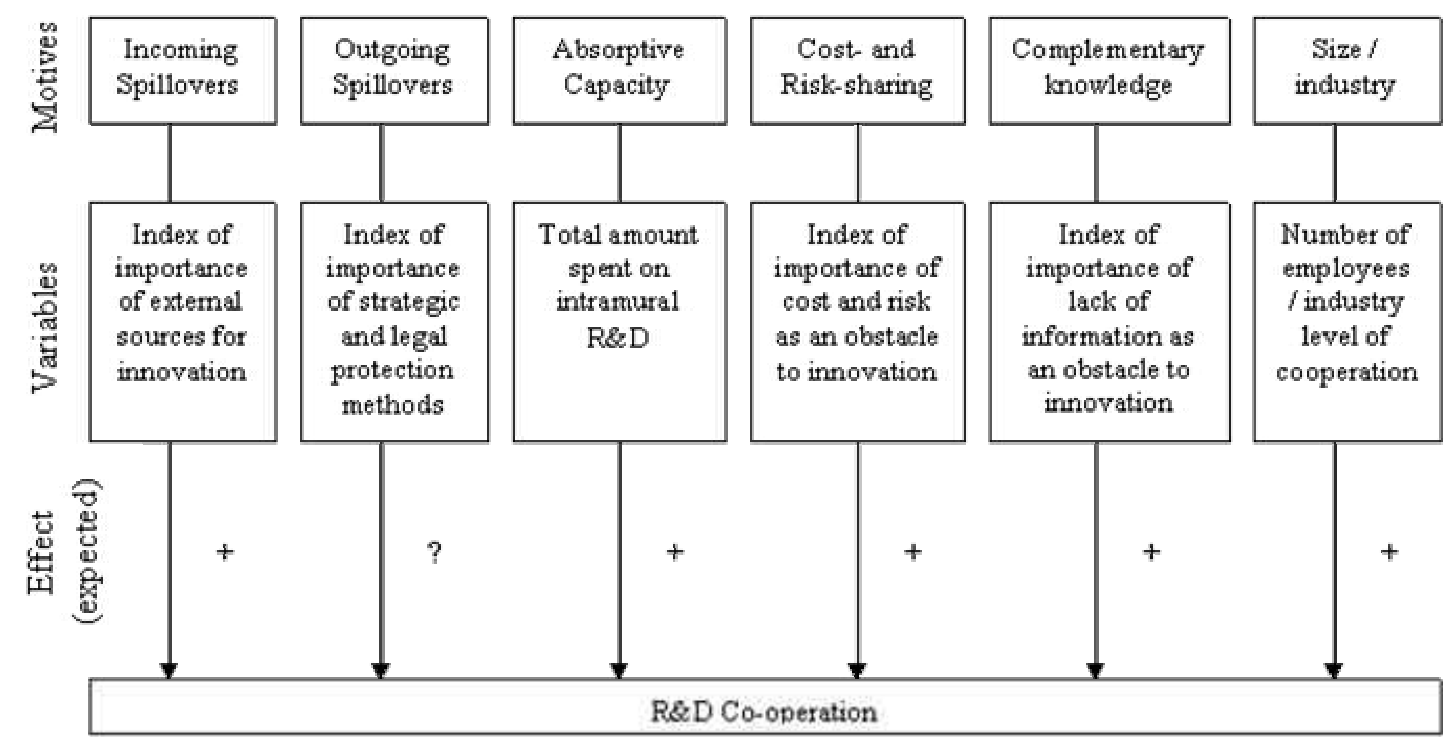

Elaborating on the blueprint presented in Figure 1, the variables used in our empirical model are outlined below. The exact construction of these variables is presented in Section 4 and the annex. 
Our main concern is investigating the impact of knowledge flows on a firm's $R \& D$ co-operation decision. The importance of external information sources, representing the knowledge flows into a firm (incoming spillovers), is thus included in the model. Two variables describing the importance of legal and strategic protection methods for inventions and innovations are included in the empirical model. The importance of protection methods is used as an inverse measure of outgoing spillovers since the use of protection methods usually limits the availability of knowledge outside a firm. In this respect formal and strategic methods differ, however. Patents for example require firms to disclose some of their knowledge and restrict the usability of this knowledge, while secrecy limits knowledge flows per se, but impose no restrictions on the usage of knowledge that nonetheless leaks out.

We follow Cohen and Levinthal (1989), who argue that R\&D activities not only generate new knowledge but also enhance a firm's ability to "identify, assimilate and exploit knowledge from the environment" (p.569) (Absorptive capacity) and thus raises its ability to profit from external sources in general and cooperation in particular, as discussed in section 2. Absorptive capacity is proxied by the total amount spent on R\&D in our model.

The motives not directly related to knowledge flows can also be investigated in our empirical model. The importance of risk and cost as obstacles to innovation activities is a fairly direct measure of the importance of the cost- and risksharing motive for R\&D co-operation, and is hence part of the empirical model. The more firms are hampered by a lack of finance for innovation activities or by excessive risk involved in potential innovative activities, the more they will be willing to share the risk with others. Complementary knowledge as a motive for R\&D co-operation is represented in our empirical model by the importance of the lack of appropriate knowledge as an obstacle to innovation. ${ }^{3}$ This is not a direct measure of the need for complementary knowledge it nonetheless reflects the need of firms to get access to knowledge which they themselves don't possess and can thus be used as a proxy.

The size of a firm and its industry are not the same kind of motives as those presented above. They nonetheless influence the decision to cooperate in R\&D

\footnotetext{
${ }^{3}$ Rocha (1999) p.256-258 provides an overview of cooperation and complementary knowledge.
} 
and are thus included in the model. The size of a firm should positively influence the likelihood of a firm being involved in at least one R\&D co-operation. As a firm's number of employees grows, it tends to be involved in more and more distinct innovation projects simultaneously. Its pool of potential co-operation partners consequently becomes larger; hence, the likelihood of a firm being involved in at least one R\&D co-operation increases. Specific features of certain industries - such as the number of enterprises -- not captured by the other variables in our empirical model are likely to have an influence on the probability to cooperate in $R \& D$ as well. If an industry is highly concentrated, for example, there are less potential co-operation partners. Additionally, innovation activities in some industries intrinsically require more external knowledge than others and should thus evince a higher probability of co-operation.

The formal empirical model looks like this:

Cooperation $_{i}^{*}=\beta^{\prime} X_{i}^{\text {coop }}+u_{i}$ with Cooperation $_{i}=\left\{\begin{array}{l}1 \text { if } \text { Cooperation }_{i}^{*}>0 \\ 0 \text { otherwise }\end{array}\right.$

where $X_{i}^{\text {coop }}$ is the column vector representing the variables presented above.

In this specification all variables are treated as exogenous. As Cassiman and Veugelers (2002) and Lopez (2004) have shown, this might not be the case for some of the variables included in our model. In our estimation, some of the variables described below should be treated as endogenous:

We assume total amount spent on intramural $R \& D$ to be endogenous since on the one hand, co-operation should lead to the reduction of a firm's own R\&D through cost- and work-sharing actions; on the other, high R\&D budgets increase the incentive to cooperate as shown in the literature.

The exogeneity of the importance of risk and/or cost as an obstacle to innovation activities is at least debatable. If a firm perceives the cost and risk of a planned innovation project to be prohibitively high, it might be inclined to cooperate with another firm in order to lower these factors. However, actually cooperating with external partners also reduces the risk and cost of projects for an 
individual firm. Lopez (2004) models the cost and risk variables as endogenous, whereas Cassiman and Veugelers (2002) do not. To yield comparable with both studies, we set up two models: One where cost and risk are treated as exogenous variables and one where the two variables are endogenous.

Similar arguments can be made with respect to the endogeniety of the variables used to capture the importance of external sources of innovation and the importance of strategic protection methods. Both influence the decision to cooperate and are at the same time influenced by the co-operation behavior of a firm. A firm which is co-operating in order to obtain knowledge from external sources is very likely to assign a higher importance to external sources than a non-cooperating firm. The same is true for strategic protection methods for innovation. The perceived importance of strategic protection methods ("appropriability" ${ }^{4}$ ) is likely to increase with co-operation, since the firm faces the problem that despite interacting with a partner more closely than without co-operation, the partners should not be able to access knowledge beyond those supposed to be exchanged through the co-operative agreement. ${ }^{5}$

To take the endogeneity of the variables into account, the simple model has been augmented and a two-step procedure introduced. In the first step we regress the endogenous variables on all the exogenous variables along with some additional instruments (see Section 4) and then calculate the predicted values of the endogenous variables. These predicted values are then used in the second stage regressions in order to find the determinants of R\&D cooperation. Since the independent variable of the structural equation is binary, it was estimated using a probit estimation procedure. According to Greene (1981), the standard errors of the second-stage coefficients would be biased if the two-step method were applied. In order to correct for this bias, we bootstrap the standard errors for the second stage.

4 In line with Cassiman and Veugelers (2002), we use the term "appropriability" for the importance of strategic protection methods.

5 Cassiman and Veugelers (2002) also argue in favour of endogenising the importance of strategic protection methods. Their argument is that this firm-level variable is subject to measurement errors which can be corrected a two-step procedure. 
The full model for the specification with the variables for cost- and risk-sharing as exogenous variables takes the following form:

Cooperation $_{i}^{*}=\alpha_{0}+\alpha_{1}{\widehat{\text { Spill_in }_{i}}}_{1}+\alpha_{2}{\widehat{\text { Approp }_{i}}}_{i}+\alpha_{3} \widehat{\text { RD_budget }}_{i}+\beta X_{i}^{\text {coop }}+u_{i}$

with

Cooperation $_{i}=\left\{\begin{array}{l}1 \text { if } \text { Cooperation }_{i} \\ 0 \text { otherwise }\end{array}\right.$

The first-step equations:

Spill_in $n_{i}=\chi_{0}+\chi^{\prime} Z_{i}+\delta^{\prime} X_{i}^{\text {coop }}+v_{i}$

Approp $_{i}=\lambda_{0}+\lambda^{\prime} Z_{i}+\sigma^{\prime} X_{i}^{\text {coop }}+e_{i}$

$R D \_$budget $t_{i}=\eta_{0}+\eta^{\prime} Z_{i}+\vartheta^{\prime} X_{i}^{\text {coop }}+k_{i}$

where $X_{i}^{\text {coop }}$ is the column vector representing the exogenous explanatory variables of the structural equation. $Z_{i}$ is the column vector of the instruments used in the first step regressions ${ }^{6}$. (see Section 3 ).

${\widehat{\text { Spill_in }_{i}}}_{\text {Approp }_{i}}, \widehat{\text { RD_Budget }}_{i}$ represent the predicted values calculated from the three first-step OLS regressions, for incoming spillovers, appropriability, and total intramural R\&D expenditures, respectively.

If the cost- and risk-sharing variables are treated as endogenous variables, two additional equations are necessary:

$$
\begin{aligned}
& \operatorname{Cost}_{i}=\varsigma_{0}+\zeta^{\prime} Z_{i}+\tau^{\prime} X_{i}^{\text {coop }}+l_{i} \\
& \operatorname{Risk}_{i}=\psi_{0}+\psi^{\prime} Z_{i}+\zeta^{\prime} X_{i}^{\text {coop }}+\omega_{i}
\end{aligned}
$$

\footnotetext{
${ }^{6}$. Angrist, J. and B. Krueger (2001) argue that it is best to use OLS regressions in the first stage even if the dependent variable is binary or censored.
} 
and the $2^{\text {nd }}$-stage equation becomes:

Cooperation $_{i}^{*}=\alpha_{0}+\alpha_{1}{\widehat{\text { Spill_in }_{i}}}_{i}+\alpha_{2} \widehat{\text { Approp }}_{i}+\alpha_{3} \widehat{\text { RD_budget }}_{i}+\alpha_{4} \widehat{\operatorname{Cost}}_{i}+\alpha_{5} \widehat{\text { Risk }}_{i}+\beta^{\prime} X_{i}^{\text {coop }}+r_{i}$

with $\widehat{\operatorname{Cost}}_{i}, \widehat{\operatorname{Risk}}_{i}$ being the two additional predicted values from the first-stage regressions.

The empirical models with which we try to explain the decision to cooperate with a specific group of partners are set up analogously.

\section{Data and Construction of the Variables}

For this study we use firm-level data from the Third Community Innovation Survey (CIS III), which was carried out in 2001 and examined innovation activities during the period 1998 - 2000. In Germany, the CIS III survey was conducted by the Center for European Economic Research (ZEW) on behalf of the German Federal Ministry of Education and Research. It is part of a larger effort to gather data on the innovation behavior of German firms in industry and services through annual innovation surveys called the Mannheim Innovation Panel (MIP). ${ }^{7}$ Since some of the questions necessary for the construction of our variables are not included in more recent MIP surveys, we used the CIS III data. CIS III was conducted in all of the EU member states (plus Norway) and allows comparisons among countries with respect to firms' innovation behavior. ${ }^{8}$ The representative survey was not mandatory in Germany, which led to significant problems with non-response.

7 A detailed description of the survey can be found in Janz et al. (2001)

8 Note that Cassiman and Veugelers (2004) and Lopez also used the CIS data for their study. This should increase the comparability of our results with theirs considerably, since all countries use a harmonized questionnaire and methodology for the Community Innovation Surveys. 
Of the 2,020 manufacturing firms which returned the questionnaire, we only use those which had been innovative. ${ }^{9}$ This reduction is necessary because only innovative firms were required to answer questions regarding their cooperative behavior and others related to innovation activities. This restriction does not pose a problem, however, as we only wish to investigate the R\&D cooperation decision and not the co-operation decision in general. Restricting our sample to innovative firms, we are left with 1,278 (63\%). However, only 1,016 of these 1,278 firms provided answers to all the questions necessary for the construction of the variables required for our analysis. The reduction of the sample to the 1,016 firms for which all data is available is likely to have introduced some selection bias, but we consider it small enough to be neglected.

The sample contains 301 (30\%) externally co-operating innovators. Of these cooperating firms, 208 cooperated with suppliers and customers and 237 with research institutions. ${ }^{10}$ The descriptive statistics show that there are differences between cooperating and non-cooperating firms not only with respect to their inward and outward knowledge flows, but also to other variables like amount of intramural R\&D.

The variables we included in the empirical model were constructed as follows ${ }^{11}$ :

Incoming Spillovers: Volume of incoming spillovers can not be measured directly using the CIS III questionnaire. In order to be able to include incoming spillovers in the model in spite of this, we included a question in which firms were asked to assess the importance of different sources of information for their innovation activities in the CIS III questionnaire. They were given four categories to choose from, ranging from not used (0) to highly important (3). To construct the incoming spillover variable we only use two of the twelve sources the firms were asked to rate, namely professional conferences, meetings and jour-

\footnotetext{
9 A firm has been labeled "innovative“ if it had either introduced a product or process innovation, had ongoing innovation projects, or abandoned innovation activities during the three year period 1998-2000.

10 Additional descriptive statistics from the sample can be found in Table 1 of the annex.

11 The construction of each variable is described in the annex.
} 
nals as one source and exhibitions and fairs as the other. ${ }^{12}$ The scores for these sources are summed up and divided by the maximum sum of scores possible (6) to rescale the firm-specific measure between zero (not used) and one (highly important).

Appropriability: To construct an inverse measure of outgoing spillovers we use information on the importance of strategic methods to protect innovations and inventions. Like the variable for incoming spillovers, this is only a proxy of the level of outgoing spillovers. The question we applied asked the firms to rate the importance of protection methods for innovations, ranging from not used (0) to highly important (3). To obtain the appropriability variable we sum up the scores for all the strategic methods (secrecy, complexity of design and lead time) and divide the total by the maximum sum possible (9) to rescale the firm-specific measure between zero (not relevant) and one (highly important).

Legal Protection: Additionally, the level of outgoing spillovers is proxied by the level of legal protection, which is constructed according to the method used for appropriability and using formal protection methods (patents, patterns, trademarks, copyrights) instead of strategic methods. The legal protection methods are treated separately since their effect on outgoing spillovers is not as distinct as that of strategic protection methods. Legal protection methods require firms to disclose some of their knowledge and thus generate a special kind of outgoing spillovers. This variable was included in the model as an industry-level variable (2digit NACE) by taking the mean of the individual scores in the industry. ${ }^{13}$

Absorptive Capacity: To capture the absorptive capacity a firm possesses we use the total amount a firm is spending on R\&D ("R\&D budget"). ${ }^{14}$ Most other empirical studies dealing with similar topics (e.g., Dachs et. al (2004) and Fontana et. al (2003)) use R\&D intensity (R\&D as a percentage of total turn-

12 This restriction was imposed to yield results comparable with studies from Spain and Belgium. This is certainly a limitation, as other sources of external knowledge (suppliers, customers, and competitors) may be more important sources for some firms.

13 This restriction was imposed to yield results comparable with those from Spain and Belgium. 14 We also estimated the equations using the logarithm of the intramural R\&D budget instead of the intramural R\&D budget itself. The results were very similar in both cases. 
over) instead of total amount of R\&D expenditures to model the absorptive capacities of a firm. In our opinion, however, total amount spent on R\&D is a better proxy for absorptive capacity than R\&D intensity since a large amount of $R \& D$ spending and not only a large share of $R \& D$ in total turnover should lead to high absorptive capacities. A small firm with a small turnover volume but a high R\&D intensity is fairly unlikely to have the same absorptive capacities as a large firm with a turnover volume significantly higher than that of the small firm and a slightly lower R\&D intensity.

Cost- and Risk-sharing: Using a question on the importance of factors hampering innovation activity, we get a direct measure of these motives; the firms were asked to assess the importance of high costs and high risk of innovation projects as an obstacle to innovation.

Complementarities: To proxy the need for complementary knowledge we again use the information on the importance of hampering factors -- to be more precise, the importance of a lack of information on technologies -- as an obstacle to innovation. If a firm perceives a lack of information on technology as an obstacle to innovation, we assume that it does not have the knowledge it needs to conduct innovation activities internally and thus has a need for complementary knowledge.

Size and Industry: In order to control for the effect of firm size and industry on a firm's R\&D co-operation decision we include number of employees and industry level of co-operation (instead of industry dummies) in our estimations. The latter is particularly controversial, as most other studies use industry dummies to capture the influence of a firm's industry on its decision to engage in cooperative agreements. Lopez (2004) and Cassiman and Veugelers (2002), however, used the industry level of the co-operation variable. Since one of the aims of this paper is to compare the results for Germany with those for Spain and Belgium, we utilize the same method.

Nevertheless, the size variable used in our study is different from that of Lopez (2004) and Cassiman and Veugelers (2002). Instead of turnover, we use num- 
ber of employees to construct our size variables. This should not influence the comparability of the two studies because turnover and number of employees are usually quite positively correlated. ${ }^{15}$

Using a two-step estimation procedure requires the use of instruments in the first stage. The following variables are thus used in the first-step OLS regressions as instruments for the endogenous variables in addition to the exogenous variables from the structural equations.

Public support of R\&D is included as an instrument for the importance of cost as an obstacle to innovation. Our argument is that financial R\&D support will decrease cost and risk for a firm undertaking a specific innovation project because it reduces demand for the firm's own funds to be used within the project.

We also use this variable as an instrument in the model treating cost and risk as exogenous. In this model it is included as an additional instrument for intramural R\&D budget since public support is normally complementary to a firm's own R\&D spending. Hence, R\&D budget should be higher when a firm receives public $R \& D$ support compared to a situation without $R \& D$ support.

Kamien and Zang (2000) have shown that the benefits of knowledge inflows increase if a firm's innovation activities are closer to basic R\&D. Thus, the level of incoming spillovers should be influenced by the "basicness of R\&D" variable used in the first-step regression. We try to capture the basicness of R\&D by calculating the ratio between the importance of public research as a source of information for innovations and the importance of information from customers and suppliers.

The level of strategic protection used by a firm depends generally on its competitive environment. We include export share in the first-stage regression to capture this effect, arguing that a firm which exports relatively more faces harder competition than firms which do not.

In addition to these instruments we included the industry level of all the variables we assume to be endogenous, i.e., the industry level of incoming spillovers, intramural R\&D budgets and appropriability in the first-step regression for

\footnotetext{
${ }^{15}$ Because we found differences in the significance of the size variables between our study and the ones by Lopez and Cassiman and Veugelers (2002), we also estimated the models using turnover to generate the size dummy, however the results didn't change significantly.
} 
specifications -- with cost and risk exogenous - along with the industry level of the cost and risk variables in specifications where these variables are endogenous.

\section{Results}

In this section we present the results of the various specifications (Table 1$)^{16}$ and compare them with the results found for Spain and Belgium. Overall, the results are similar to those of the two other countries: Incoming spillovers and appropriability play an important role in determining $R \& D$ co-operation in most cases. The main difference is that legal protection measures are very important in the German case for firms' decisions to engage in R\&D co-operation. They were of minor importance in Spain and Belgium.

This encourages a closer look at the German results for the outgoing spillover variables. In all specifications the level of legal protection exerts a negative influence, while the appropriability variable is positively significant. The more important formal means of protection are for an industry, the less likely firms in that industry are to cooperate. One explanation is that firms in industries associated with a substantial amount of patenting are more concerned with information leaking out to their competitors than those involved in less patent-intensive sectors. They are more reserved when it comes to co-operation since they want to keep their proprietary knowledge, which they have in addition to the knowledge released in their patent applications, to themselves.

Furthermore, if legal protection methods are very important in an industry, this can be interpreted as an indicator that a lot of firms use protection methods that require them to disclose some of their knowledge. The pool of knowledge disseminated through legal protection methods is thus relatively large in industries which use legal protection methods intensively. As discussed in Section 2, a large pool of outgoing spillovers increases the incentive to free ride on others' $R \& D$ investments and thus decreases the incentive to cooperate. This view is supported by our results.

\footnotetext{
${ }^{16}$ The results for the first step regressions can be found in the Annex.
} 
Table 1: Marginal effects for Probit Estimations of Probability of Co-operation

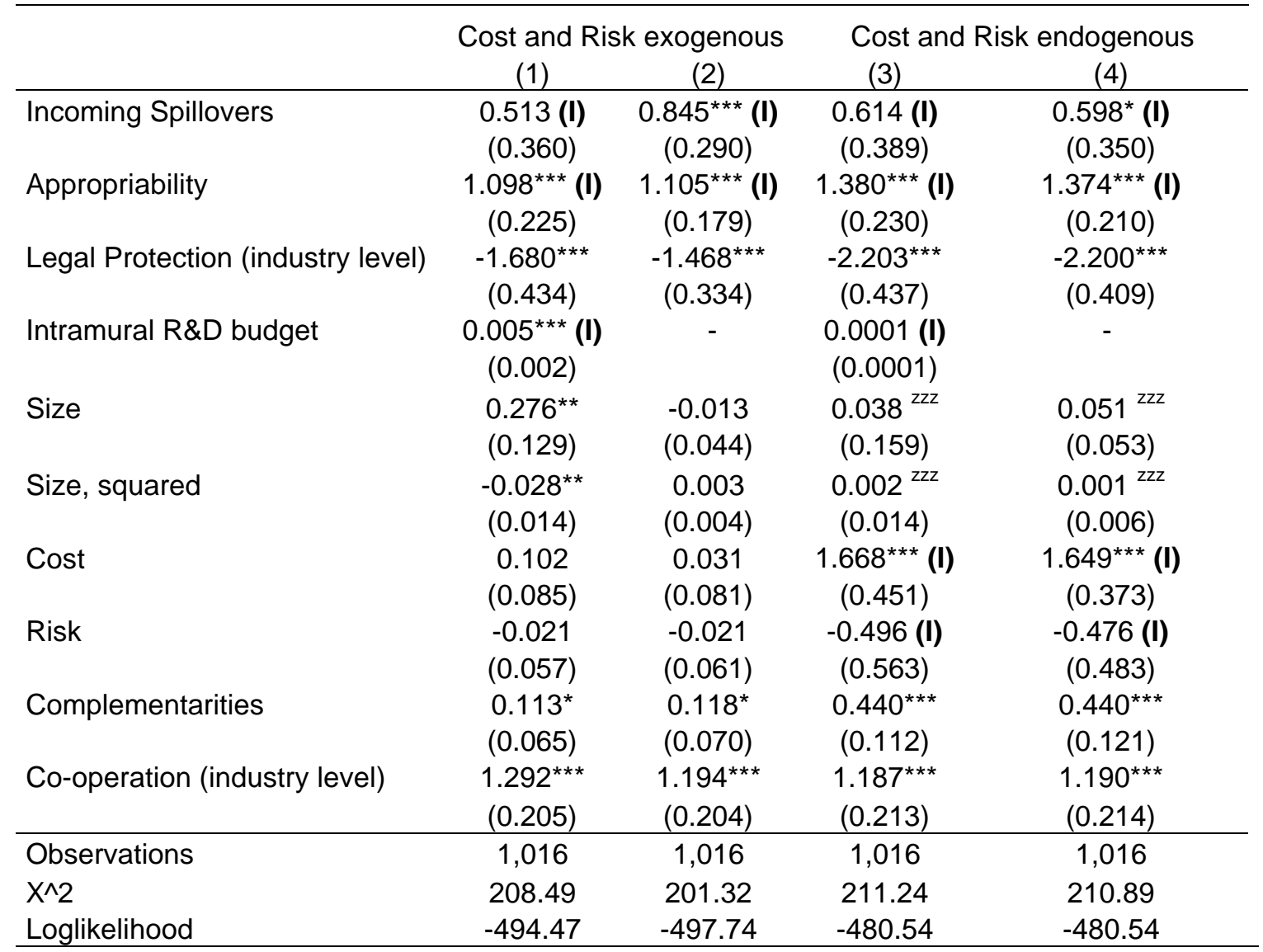

*** significant at $1 \% ;{ }^{* *}$ significant at $5 \% ;{ }^{*}$ significant at $10 \%$

zzz jointly significant at $1 \% ;{ }^{z z}$ jointly significant at $5 \% ;{ }^{z}$ jointly significant at $10 \%$

(I) Instrumented; Robust standard errors in parentheses (bootstrapped to correct for bias induced by two-step procedure)

For the second measure of outgoing spillovers, appropriability, we find a positive and significant sign in all of the equations. This variable measures the importance of strategic protection methods which do not require firms to disclose any knowledge per se, but rather limit the outflow of knowledge directly. The usage of strategic protection methods by other firms thus reduces the level of knowledge freely available to any single firm and consequently increases the incentive to cooperate as a means of obtaining access to external knowledge. Another reason for the positive and significant influence of the appropriability variable is that if a firm is able to protect most of its own knowledge through strategic protection methods, it is very likely to be able to control the exchange of knowledge in a cooperative relationship as well. This would reduce the risk of involuntary spillovers in said cooperative agreement and should increase the firm's incentive to co-operate. 
Incoming spillovers have a positive influence on the probability of $R \& D$ cooperation. However, the empirical evidence is not as strong as for the measures of outgoing spillovers. In the equations including the intramural R\&D budget variable, which is supposed to measure absorptive capacity, the incoming spillover variable is insignificant, whereas excluding the intramural $R \& D$ budget yields a significant effect of incoming spillovers on co-operation. One explanation is that level of absorptive capacity and that of incoming spillovers are correlated to a certain extent, which should be the case according to theory: Higher absorptive capacities increase a firm's ability to assimilate external knowledge, thereby increasing its level of both potential and actual incoming spillovers. Our research counterparts In Belgium and Spain found positive and significant signs for incoming spillovers regardless of the endogeneity structure used and the inclusion or exclusion of a measure of absorptive capacity ${ }^{17}$.

Another result that is similar among equations (1) to (4) is the role of complementary knowledge in determining the probability of co-operation. In all four equations the probability of a firm engaging in R\&D co-operation is higher if its need for complementary knowledge is more pronounced. Gaining access to complementary technological knowledge can thus indeed be considered a motive for co-operation. The detailed analysis by type of co-operation partner (see below), however, shows that only some types of co-operation are influenced by a need for complementary knowledge, among them co-operation with research institutions.

The evidence pointing to financial constraints is mixed: On the one hand we find a positive and significant sign for lack of financial resources on the probability of R\&D co-operation with cost and risk as endogenous variables; on the other, lack of financial resources does not influence the decision to form an $R \& D$ co-operation significantly if cost and risk are treated as exogenous.

The risk variable has a negative sign in all four equations, but it is not significant. Upon first glance the negative sign (also found by Cassiman and Veugelers (2002) in Belgium) for increased risk is surprising, since one would expect the incentive to share a project's risk with other firms in a co-operation to

\footnotetext{
${ }^{17}$ Note that Cassiman and Veugelers (2002) also found a decrease of the significance level of the incoming spillover variable if including a measure for absorptive capacity.
} 
increase with that risk. Cassiman and Veugelers (2002) ${ }^{18}$ used the transactions-cost approach to explain the negative sign: As projects become more complex and risky, it may be harder to come up with good contracts minimizing partners' opportunistic behavior.

No definite picture emerges for the intramural R\&D budget variable. Depending on the endogeneity structure of the model, this variable is significant or it is not. The highly positive and significant sign in equation (1) together with the positive sign in equation (3) at least give some indication that the amount spent on $R \& D$ positively influences the probability of co-operation. The lack of a more significant influence could be explained by higher levels of absorptive capacity not only influencing the likelihood of profits from knowledge transferred in a cooperative agreement but also the possibility of gains from knowledge freely available outside the cooperative agreement. If a firm is able to utilize more outside knowledge as a result of an increase in its absorptive capacity, it may be less willing to join a cooperative agreement and share its own knowledge with others.

Table 2 shows the results of the models used to investigate the determinants of decisions to co-operate with different types of partners.

Regardless of the endogeneity structure used and the inclusion or exclusion of the R\&D budget variable, we find that incoming spillovers do affect the probability of co-operation with research institutions positively and significantly. Appropriability and the level of legal protection in an industry are common motives behind firms' decisions to cooperate or forego co-operation despite potential partners.

As one would expect, intramural R\&D positively influences the likelihood of cooperation with research institutes but does not effect decisions on co-operating with suppliers. One possible explanation is that absorptive capacities built up through a firm's own R\&D spending may be more useful in accessing the more basic knowledge resources of universities and research institutes and influence the ability to use suppliers' knowledge only slightly.

${ }^{18}$ Cassiman and Veugelers (2002) p.11 
Table 2: Marginal Effects for 2-Step Probit Estimations of Probability of Co-operation with Customers/Suppliers and Research Institutions

\begin{tabular}{|c|c|c|c|c|c|c|c|c|}
\hline & \multicolumn{4}{|c|}{ Co-operation with suppliers and customers } & \multicolumn{4}{|c|}{ Co-operation with research institutions } \\
\hline & (5) & (6) & $(7)$ & (8) & $(9)$ & $(10)$ & $(11)$ & $(12)$ \\
\hline Incoming Spillovers & $\begin{array}{c}0.027(I) \\
(0.265)\end{array}$ & $\begin{array}{c}0.188(I) \\
(0.267)\end{array}$ & $\begin{array}{c}0.021(I) \\
(0.206)\end{array}$ & $\begin{array}{c}0.188(I) \\
(0.267)\end{array}$ & $\begin{array}{c}0.764^{* * *}(\mathrm{I}) \\
(0.288)\end{array}$ & $\begin{array}{c}1.072^{* * *}(\mathrm{I}) \\
(0.249)\end{array}$ & $\begin{array}{c}0.453^{* *}(I) \\
(0.171)\end{array}$ & $\begin{array}{c}0.488^{\star *}(\mathrm{I}) \\
(0.114)\end{array}$ \\
\hline Appropriability & $\begin{array}{c}0.544^{\star * *}(I) \\
(0.189)\end{array}$ & $\begin{array}{c}0.545^{\star * *}(\mathrm{I}) \\
(0.161)\end{array}$ & $\begin{array}{c}0.628^{* * *}(\mathbf{I}) \\
(0.219)\end{array}$ & $\begin{array}{c}0.545^{\star * *}(\mathrm{I}) \\
(0.161)\end{array}$ & $\begin{array}{c}1.234^{\star \star *}(\mathbf{I}) \\
(0.191)\end{array}$ & $\begin{array}{c}1.229^{* * *}(\mathbf{I}) \\
(0.174)\end{array}$ & $\begin{array}{c}1.388^{* * *}(\mathrm{I}) \\
(0.215)\end{array}$ & $\begin{array}{c}1.398^{* * *}(\mathbf{I}) \\
(0.198)\end{array}$ \\
\hline Legal Protection (industry level) & $\begin{array}{c}-0.693^{\star *} \\
(0.319)\end{array}$ & $\begin{array}{c}-0.637^{* *} \\
(0.227)\end{array}$ & $\begin{array}{c}-0.896^{\star *} \\
(0.412)\end{array}$ & $\begin{array}{l}-0.637^{\star *} \\
(0.227)\end{array}$ & $\begin{array}{c}-1.808^{* * *} \\
(0.378)\end{array}$ & $\begin{array}{c}-1.598^{\star * *} \\
(0.354)\end{array}$ & $\begin{array}{c}-1.846^{\star * *} \\
(0.386)\end{array}$ & $\begin{array}{c}-1.780^{\star \star *} \\
(0.394)\end{array}$ \\
\hline Intramural R\&D Budget & $\begin{array}{c}0.002(\mathrm{I}) \\
(0.001)\end{array}$ & - & $\begin{array}{c}0.001 \text { (I) } \\
(0.001)\end{array}$ & - & $\begin{array}{c}0.005^{\star * *}(\mathrm{I}) \\
(0.002)\end{array}$ & - & $\begin{array}{c}0.002^{* * *}(I) \\
(0.001)\end{array}$ & - \\
\hline Size & $\begin{array}{l}0.144^{z z} \\
(0.099)\end{array}$ & $\begin{array}{c}0.011^{z z z} \\
(0.035)\end{array}$ & $\begin{array}{c}0.092^{z z z} \\
(0.063)\end{array}$ & $\begin{array}{c}0.011^{z z z} \\
(0.035)\end{array}$ & $\begin{array}{l}0.226^{\star *} \\
(0.103)\end{array}$ & $\begin{array}{l}-0.038 \\
(0.036)\end{array}$ & $\begin{array}{l}0.130 \text { ** } \\
(0.059)\end{array}$ & $\begin{array}{c}0.047^{z z z} \\
(0.044)\end{array}$ \\
\hline Size, squared & $\begin{array}{c}-0.012^{z z} \\
(0.010)\end{array}$ & $\begin{array}{c}0.002^{z z z} \\
(0.003)\end{array}$ & $\begin{array}{c}-0.005^{z z z} \\
(0.004)\end{array}$ & $\begin{array}{c}0.002^{z z z} \\
(0.003)\end{array}$ & $\begin{array}{c}-0.025^{\star *} \\
(0.011)\end{array}$ & $\begin{array}{c}0.004 \\
(0.004)\end{array}$ & $\begin{array}{l}-0.010 \text { ** } \\
(0.004)\end{array}$ & $\begin{array}{c}-0.001^{z z z} \\
(0.001)\end{array}$ \\
\hline Cost & $\begin{array}{c}0.033 \\
(0.063)\end{array}$ & $\begin{array}{l}0.0001 \\
(0.255)\end{array}$ & $\begin{array}{c}0.518(\mathrm{I}) \\
(0.996)\end{array}$ & $\begin{array}{c}0.000(\mathrm{I}) \\
(0.255)\end{array}$ & $\begin{array}{c}0.119 \\
(0.073)\end{array}$ & $\begin{array}{c}0.053 \\
(0.067)\end{array}$ & $\begin{array}{c}1.411(\mathrm{I}) \\
(0.871)\end{array}$ & $\begin{array}{c}1.459^{*}(\mathrm{I}) \\
(0.846)\end{array}$ \\
\hline Risk & $\begin{array}{c}0.040 \\
(0.047)\end{array}$ & $\begin{array}{c}0.039 \\
(0.049)\end{array}$ & $\begin{array}{c}-0.092(\mathrm{I}) \\
(0.109)\end{array}$ & $\begin{array}{c}0.039(I) \\
(0.049)\end{array}$ & $\begin{array}{l}-0.094^{*} \\
(0.055)\end{array}$ & $\begin{array}{l}-0.091^{*} \\
(0.051)\end{array}$ & $\begin{array}{c}-0.113^{*}(\mathrm{I}) \\
(0.066)\end{array}$ & $\begin{array}{c}-0.106 *(I) \\
(0.059)\end{array}$ \\
\hline Complementarities & $\begin{array}{c}0.051 \\
(0.050)\end{array}$ & $\begin{array}{c}0.054 \\
(0.051)\end{array}$ & $\begin{array}{c}0.156 \\
(0.152)\end{array}$ & $\begin{array}{c}0.054 \\
(0.051)\end{array}$ & $\begin{array}{l}0.132^{\star *} \\
(0.059)\end{array}$ & $\begin{array}{l}0.140^{* * *} \\
(0.055)\end{array}$ & $\begin{array}{l}0.481^{* *} \\
(0.261)\end{array}$ & $\begin{array}{l}0.499^{* * *} \\
(0.198)\end{array}$ \\
\hline $\begin{array}{l}\text { Co-operation with suppliers and } \\
\text { customers (industry level) }\end{array}$ & $\begin{array}{l}1.019^{* * *} \\
(0.222)\end{array}$ & $\begin{array}{l}1.003^{* * *} \\
(0.208)\end{array}$ & $\begin{array}{l}0.996^{* * *} \\
(0.217)\end{array}$ & $\begin{array}{l}1.003^{* * *} \\
(0.208)\end{array}$ & - & - & - & - \\
\hline $\begin{array}{l}\text { Co-operation with Research Institu- } \\
\text { tions (industry level) }\end{array}$ & - & - & - & - & $\begin{array}{l}1.297^{\star * *} \\
(0.211) \\
\end{array}$ & $\begin{array}{l}1.197^{\star * *} \\
(0.213)\end{array}$ & $\begin{array}{l}0.965^{* * *} \\
(0.157) \\
\end{array}$ & $\begin{array}{l}0.916^{* * *} \\
(0.163)\end{array}$ \\
\hline Observations & 1,016 & 1,016 & 1,016 & 1,016 & 1,016 & 1,016 & 1,016 & 1,016 \\
\hline $\begin{array}{l}X^{\wedge} 2 \\
\text { Loglikelihood }\end{array}$ & $\begin{array}{c}155.57 \\
-430.67\end{array}$ & $\begin{array}{c}150.34 \\
-431.73\end{array}$ & $\begin{array}{c}154.71 \\
-428.97\end{array}$ & $\begin{array}{c}150.34 \\
-431.73\end{array}$ & $\begin{array}{l}227.80 \\
-391.10\end{array}$ & $\begin{array}{c}223.79 \\
-394.94\end{array}$ & $\begin{array}{l}221.65 \\
-372.78\end{array}$ & $\begin{array}{c}223.17 \\
-373.29\end{array}$ \\
\hline
\end{tabular}

${ }^{* * *}$ significant at 1\%; ${ }^{* *}$ significant at $5 \% ;{ }^{*}$ significant at $10 \% ;{ }^{\text {zzz }}$ jointly significant at $1 \% ;{ }^{\text {zz }}$ jointly significant at $5 \%$; (I) Instrumented

Robust standard errors in parentheses (bootstrapped to correct for bias induced by two-step procedure) 
One other motive that exclusively influences the decision to cooperate with universities is risk-sharing (negative and significant). The negative sign of the risk variable can be explained by assuming that a firm decides simultaneously on the type of partner it wants to engage. If the perceived risk involved in a project is too high, it is more likely to choose to engage a partner that can contribute significant financial resources and experience rather than significant technological information. Assuming, that these resources and skills can be more easily contributed by a commercial firm than by a research institution, firms may be inclined to approach the former instead of the latter. The positive sign of the cost variable in equation (12) offers no contradiction to this argument. It measures lack of appropriate financing for innovation projects. In the case of such a lack, it might be cheaper to obtain knowledge from a university or research institute than from a customer or supplier, regardless of the risk involved in a project.

The results also suggest that firms perceive the strength of research institutes to lie in the production of relevant and valuable technological knowledge. If firms see a lack of appropriate know-how on a certain technology as a factor hampering their innovation activities, they are more likely to co-operate with research institutions than suppliers or customers.

\section{Conclusion}

All of our estimations show that knowledge-flows matter for the R\&D cooperation decision of a firm. Outgoing spillovers or their prevention have a particularly significant influence on the propensity to cooperate in innovation projects.

The role of absorptive capacity, measured by amount of intramural R\&D expenditure, in determining the probability of a firm co-operating in R\&D is less clear. We only find a small positive influence for level of $R \& D$ spending on the likelihood of co-operation. For the decision to cooperate with research institutes, however, absorptive capacity is a very important requirement. To improve the understanding of the role of absorptive capacity in R\&D co-operation decisions 
in general, future studies will have to investigate more appropriate measures of absorptive capacity in greater detail.

While the results for spillovers are in line with those found in Spain and Belgium, a unique result for the German case is that legal protection methods are very important. They have a much more prominent role in determining R\&D cooperation than in other countries that have been studied in similar frameworks thus far. We also found that the influence of legal protection methods on the cooperation decision is quite different from that of strategic protection methods.

The analysis by type of co-operation partner shows that there is indeed a difference between motives, especially risk-sharing and absorptive capacity, for cooperating with specific partners. The results suggest that firms do not decide independently on the type of partners they want to cooperate with. This should be taken into account for future studies of this type. With a simultaneous equation approach one could also test for complementarities between different types of $R \& D$ co-operation.

As more and more innovation subsidies are funneled into fostering cooperation and knowledge spillovers ${ }^{19}$, it is certainly interesting to see what effect public R\&D funding has on the propensity to co-operate.

One other aspect that was excluded from our analysis (but is certainly worth considering) is a distinction between foreign and domestic co-operation partners and spillovers.

19 The sixth framework program of the European Union, for example. 


\section{References}

Angrist, J.D. and A.B. Krueger (2001), Instrumental Variables and the Search for Identification: From Supply and Demand to Natural Experiments., Journal of Economic Perspectives 15 (4), 69-85.

Belderbos, R., M.A. Carree, B. Diederen, B. Lokshin and R. Veugelers (2004), Heterogeneity in R\&D cooperation strategies, International Journal of Industrial Organization 22 (7), 1237-1263

Caloghirou, Y.I., S. Vonortas and S. Nicholas (2003), Research Joint Ventures., Journal of Economic Surveys 17 (4), 541-570.

Cassiman, B. and R. Veugelers (2002), R\&D Cooperation and spillovers: Some empirical evidence from Belgium, American Economic Review 44 (3), 1169-1184.

Cohen, W.M. and D.A. Levinthal (1989), Innovation and Learning: The two faces of R\&D, Economic Journal 99 (397), 569-596.

Dachs, B., B. Ebersberger and A. Pyka (2004), Why do Firms Co-coperate for Innovation? A comparison of Austrian and Finnish CIS 3 results, Volkswirtschaftliche Diskussionsreihe der Uni Augsburg, no. 255

de Bondt, R. and R. Veugelers (1991), Strategic investment with spillovers, European Journal of Political Economy 7 , 345-366.

Fontana, R., A. Geuna and M. Matt (2003), Firm Size and Openness: The Driving Forces of University-Industry Collaboration, SPRU Working Paper Series, no. 103

Greene, W. (1981), Sample Selection Bias as a Specification Error: A Com ment, Econometrica 49, 795-98.

Greenlee, P. and B. Cassiman (1999), Product market objectives and the formation of research joint ventures., Managerial \& Decision Economics 20 (3), 115-130.

Hagedoorn, J. (1993), Understanding the rationale of strategic technology partnering: Interorganizational modes of cooperation and sectoral differences., Strategic Management Journal 14 (5), 371-385.

Janz, N., G. Ebling, S. Gottschalk and H. Niggemann (2001), The Mannheim Innovation Panels (MIP and MIP-S) of the Centre for European Economic Research (ZEW), Journal of Applied Social Science Studies 121 (1), 123-129. 
Kaiser, U. (2002), An empirical test of models explaining research expenditures and research cooperation: evidence for the German service sector., International Journal of Industrial Organization 20, 747-774.

Kamien, M.I. and I. Zang (2000), Meet me halfway: research joint ventures and absorptive capacity., International Journal of Industrial Organization 18 (7), 995-1012.

Kesteloot, K. and R. Veugelers (1995), Stable R\&D cooperation with spillovers, Journal of Economics and Management Strategy 4 (4), 651-672.

Lopez, A. (2004), Determinants for R\&D Cooperation: Evidence from Spanish manufacturing firms, mimeo.

Rocha, F. (1999), Inter-firm technological cooperation: effects of absorptive capacity, firm-size and specialization, Economics of Innovation \& New Technology 8 (3), 253-271.

Röller, L., M. Tombak and R. Siebert (1997), Why firms form Research Joint Ventures: theory and evidence, CEPR Discussion paper Series, no. 1654

Sakakibara, M. (1997), Heterogeneity of firm capabilities and cooperative research and development: An empirical Examination of Motives, Strategic Management Journal 18 (6), 143-165.

Tether, B. (2002), Who co-coperates for innovation, and why: an empirical analysis, Research Policy 31, 947-967.

Veugelers, R. (1997), Internal R\&D Expenditures and External Technology Sourcing, Research Policy 26 (3), 303-315.

Veugelers, R. and B. Cassiman (2003), R\&D Cooperation between Firms and Universities, some empirical evidence from Belgian Manufacturing, Onderzoeksrapport, no. 0325 


\section{Annex}

\section{Construction of Variables}

Appropriability: Sum of importance (number between 0 (not used) and 3 (high)) of strategic protection methods for innovations (secrecy, complexity of design and lead-time advantage). Rescaled between 0 (not used) and 1 (highly important).

Basicness of R\&D: Sum of importance (number between 0 (not used) and 3 (high)) of university and government or private non-profit research institutes as sources of information over sum of importance (number between 0 (not used) and 3 (high)) of suppliers and customers as sources of information

Intramural R\&D Budget: Amount spent on innovation activities in the year 2000 (in millions of euros).

Co-operation: One, if the firm co-operated with suppliers, customers, competitors, consultants, commercial research institutions, universities or public research institutions during the period 1998 - 2000.

Co-operation with suppliers and customers: One, if the firm co-operated with suppliers or customers during the period $1998-2000$.

Co-operation with research institutions: One, if the firm co-operated with commercial research institutions, universities or public research institutions during the period $1998-2000$.

Complementarities: Importance (number between 0 (not used) and 3 (high)) of lack of information on technology as an obstacle to innovation. Rescaled between 0 (not important) and 1 (very important). 
Cost: Sum of importance (number between 0 (not used) and 3 (high)) of obstacles to innovations related to costs (Lack of appropriate sources of financing, costs too high). Rescaled between 0 (no obstacle) and 1 (very important obstacle).

Export Share 2000: Total exports in 2000 divided by total turnover in 2000.

Incoming Spillovers: Sum of importance (number between 0 (not used) and 3 (high)) of professional conferences, meetings and journals and of exhibitions and fairs as sources of innovation. Rescaled between 0 (no spillovers) and 1 (maximum spillovers).

Intramural R\&D budget: Amount spent on intramural R\&D in 2000 (in million of euros)

Legal Protection: Sum of importance (number between 0 (not used) and 3 (high)) of formal protection methods for innovations (patents, copyrights, trademarks, registration of design patterns). Rescaled between 0 (not used) and 1 (highly used).

Risk: Importance (number between 0 (not used) and 3 (high)) of high economic risk as an obstacles to innovations. Rescaled between 0 (no obstacle) and 1 (very important obstacle)

Size: Natural logarithm of number of employees in 2000

Size^2: Natural logarithm of number of employees in 2000, squared

Industry level of variable: Mean of the variable at the 2-digit NACE level. 
Table 3 : Descriptive Statistics ${ }^{\text {a }}$

\begin{tabular}{lccccc}
\hline & $\begin{array}{c}\text { Mean } \\
\text { Sample } \\
\text { Mean }\end{array}$ & $\begin{array}{c}\text { Mean } \\
\text { Non-Co- } \\
\text { operating } \\
\text { Firms }\end{array}$ & $\begin{array}{c}\text { Mean } \\
\text { Co-operating } \\
\text { Firms }\end{array}$ & $\begin{array}{c}\text { Mean }{ }^{b} \\
\text { co-operation } \\
\text { with suppliers with research } \\
\text { or customers }\end{array}$ & $\begin{array}{c}\text { Mean } \\
\text { institutions }\end{array}$ \\
\hline Observations & 1016 & 715 & 301 & 208 & 237 \\
\% of total & - & $70 \%$ & $30 \%$ & $20 \%$ & $23 \%$ \\
\hline Incoming Spillovers & 0,563 & 0,552 & $0,589^{* *}$ & $0,594^{* *}$ & $0,610^{* * *}$ \\
& $(0,259)$ & $(0,256)$ & $(0,263)$ & $(0,258)$ & $(0,257)$ \\
\hline Appropriability & 0,342 & 0,281 & $0,486^{* * *}$ & $0,512^{* * *}$ & $0,514^{* * *}$ \\
& $(0,337)$ & $(0,322)$ & $(0,327)$ & $(0,325)$ & $(0,323)$ \\
\hline Legal Protection (industry level) & 0,191 & 0,182 & $0,211^{* * *}$ & $0,213^{* * *}$ & $0,215^{* * *}$ \\
& $(0,070)$ & $(0,072)$ & $(0,061)$ & $(0,059)$ & $(0,060)$ \\
\hline Size & 4,914 & 4,568 & $5,736^{* * *}$ & $5,969^{* * *}$ & $5,967^{* * *}$ \\
& $(1,686)$ & $(1,481)$ & $(1,855)$ & $(1,897)$ & $(1,906)$ \\
\hline Intramural R\&D budgets & 6,930 & 1,045 & $20,91^{* * *}$ & $24,33^{* * *}$ & $26,32^{* * *}$ \\
& $(70,61)$ & $(4,473)$ & $(128,6)$ & $(143,8)$ & $(144,5)$ \\
\hline Cost & 0,566 & 0,556 & $0,590^{* *}$ & 0,573 & $0,601^{* *}$ \\
& $(0,295)$ & $(0,297)$ & $(0,289)$ & $(0,280)$ & $(0,285)$ \\
\hline Risk & 0,582 & 0,558 & $0,640^{* * *}$ & $0,643^{* * *}$ & $0,648^{* * *}$ \\
& $(0,324)$ & $(0,326)$ & $(0,313)$ & $(0,309)$ & $(0,310)$ \\
\hline Complementarities & 0,688 & 0,688 & 0,689 & 0,691 & 0,691 \\
& $(0,266)$ & $(0,272)$ & $(0,253)$ & $(0,247)$ & $(0,257)$ \\
\hline a & & & & &
\end{tabular}

a standard errors in parenthesis

b mean difference between non-cooperating and cooperating firms:

*** significant at $1 \%$ level ; ${ }^{* *}$ significant at $5 \%$ level ; ${ }^{*}$ significant at $10 \%$ level 
Table 4: Regression Results, First Step Used in Equations 1 and 2

\begin{tabular}{|c|c|c|c|}
\hline & $\begin{array}{l}\text { Incoming spillovers } \\
\text { (A) }\end{array}$ & $\begin{array}{l}\text { Appropriability } \\
\text { (B) }\end{array}$ & $\begin{array}{c}\text { Intramural } \\
\text { R\&D budget } \\
\text { (C) }\end{array}$ \\
\hline Size & $\begin{array}{c}0.022 \\
(0.018)\end{array}$ & $\begin{array}{c}0.013 \\
(0.026)\end{array}$ & $\begin{array}{l}-54.121^{* *} \\
(24.574)\end{array}$ \\
\hline Size, squared & $\begin{array}{l}-0.001 \\
(0.002)\end{array}$ & $\begin{array}{c}0.002 \\
(0.002)\end{array}$ & $\begin{array}{l}6.000^{* *} \\
(2.663)\end{array}$ \\
\hline Legal Protection (industry level) & $\begin{array}{l}-0.213 \\
(0.204)\end{array}$ & $\begin{array}{l}-0.269 \\
(0.255)\end{array}$ & $\begin{array}{l}-60.863^{*} \\
(33.091)\end{array}$ \\
\hline Cost & $\begin{array}{l}0.108^{* * *} \\
(0.035)\end{array}$ & $\begin{array}{c}0.017 \\
(0.044)\end{array}$ & $\begin{array}{l}-8.387 \\
(6.952)\end{array}$ \\
\hline Risk & $\begin{array}{c}0.020 \\
(0.031)\end{array}$ & $\begin{array}{c}0.035 \\
(0.039)\end{array}$ & $\begin{array}{l}2.610 \\
(5.497)\end{array}$ \\
\hline Complementarities & $\begin{array}{l}-0.072^{* *} \\
(0.030)\end{array}$ & $\begin{array}{l}-0.010 \\
(0.041)\end{array}$ & $\begin{array}{l}-3.173 \\
(6.192)\end{array}$ \\
\hline Basicness of $R \& D$ & $\begin{array}{l}0.061^{* \star *} \\
(0.015)\end{array}$ & $\begin{array}{l}0.080^{* * *} \\
(0.021)\end{array}$ & $\begin{array}{c}2.229 \\
(2.645)\end{array}$ \\
\hline Export share 2000 & $\begin{array}{l}-0.025 \\
(0.036)\end{array}$ & $\begin{array}{l}0.186^{* * *} \\
(0.045)\end{array}$ & $\begin{array}{l}-2.510 \\
(8.121)\end{array}$ \\
\hline Public R\&D Support & $\begin{array}{c}0.008 \\
(0.018)\end{array}$ & $\begin{array}{c}0.002 \\
(0.021)\end{array}$ & $\begin{array}{l}6.722^{\star *} \\
(2.731)\end{array}$ \\
\hline Co-operation (industry level) & $\begin{array}{l}-0.117 \\
(0.088)\end{array}$ & $\begin{array}{l}-0.103 \\
(0.116)\end{array}$ & $\begin{array}{l}-24.937 \\
(21.945)\end{array}$ \\
\hline Incoming Spillovers (industry level) & $\begin{array}{c}0.779^{* * *} \\
(0.133)\end{array}$ & $\begin{array}{l}-0.143 \\
(0.163)\end{array}$ & $\begin{array}{c}14.998 \\
(19.494)\end{array}$ \\
\hline Appropriability (industry level) & $\begin{array}{c}0.092 \\
(0.171)\end{array}$ & $\begin{array}{l}1.106^{\star * \star} \\
(0.209)\end{array}$ & $\begin{array}{l}46.271^{* *} \\
(23.316)\end{array}$ \\
\hline Intramural $R \& D$ budget (industry level) & $\begin{array}{c}0.001 \\
(0.001)\end{array}$ & $\begin{array}{l}-0.000 \\
(0.001)\end{array}$ & $\begin{array}{l}0.828^{*} \\
(0.484)\end{array}$ \\
\hline Constant & $\begin{array}{c}0.072 \\
(0.087) \\
\end{array}$ & $\begin{array}{l}-0.076 \\
(0.111) \\
\end{array}$ & $\begin{array}{c}104.899^{* \star} \\
(49.143)\end{array}$ \\
\hline $\begin{array}{l}\text { Observations } \\
\text { R-squared }\end{array}$ & $\begin{array}{l}1,016 \\
0.10\end{array}$ & $\begin{array}{l}1,016 \\
0.17\end{array}$ & $\begin{array}{l}1,016 \\
0.24\end{array}$ \\
\hline
\end{tabular}


Table 5: Regression Results, First Step Used in Equations 3 and 4

\begin{tabular}{|c|c|c|c|c|c|}
\hline & $\begin{array}{l}\text { Incoming } \\
\text { spillovers } \\
\text { (D) }\end{array}$ & $\begin{array}{l}\text { Appropriability } \\
\text { (E) }\end{array}$ & $\begin{array}{c}\text { Intramural } \\
\text { R\&D budget } \\
\text { (F) }\end{array}$ & $\begin{array}{l}\text { Risk } \\
\text { (G) }\end{array}$ & $\begin{array}{c}\text { Cost } \\
(\mathrm{H})\end{array}$ \\
\hline Size & $\begin{array}{c}0.015 \\
(0.018)\end{array}$ & $\begin{array}{c}0.010 \\
(0.026)\end{array}$ & $\begin{array}{l}-53.895^{\star *} \\
(24.363)\end{array}$ & $\begin{array}{c}-0.066^{* * *} \\
(0.022)\end{array}$ & $\begin{array}{c}-0.053^{\star \star *} \\
(0.019)\end{array}$ \\
\hline Size, squared & $\begin{array}{l}-0.000 \\
(0.002)\end{array}$ & $\begin{array}{c}0.003 \\
(0.002)\end{array}$ & $\begin{array}{l}6.014^{\star \star} \\
(2.652)\end{array}$ & $\begin{array}{c}0.007^{\star \star *} \\
(0.002)\end{array}$ & $\begin{array}{c}0.002 \\
(0.002)\end{array}$ \\
\hline Legal Protection (industry level) & $\begin{array}{l}-0.035 \\
(0.219)\end{array}$ & $\begin{array}{l}-0.197 \\
(0.271)\end{array}$ & $\begin{array}{l}-78.220^{* *} \\
(38.379)\end{array}$ & $\begin{array}{l}-0.311 \\
(0.271)\end{array}$ & $\begin{array}{l}0.065 \\
(0.244)\end{array}$ \\
\hline Complementarities & $\begin{array}{c}-0.113^{* * *} \\
(0.029)\end{array}$ & $\begin{array}{l}-0.028 \\
(0.038)\end{array}$ & $\begin{array}{l}-1.489 \\
(6.424)\end{array}$ & $\begin{array}{c}-0.337^{* * *} \\
(0.039)\end{array}$ & $\begin{array}{c}-0.311^{* * *} \\
(0.034)\end{array}$ \\
\hline Basicness of $R \& D$ & $\begin{array}{c}0.065^{\star \star \star} \\
(0.016)\end{array}$ & $\begin{array}{c}0.082^{* * *} \\
(0.021)\end{array}$ & $\begin{array}{l}2.021 \\
(2.597)\end{array}$ & $\begin{array}{l}0.044^{\star *} \\
(0.018)\end{array}$ & $\begin{array}{l}0.032^{*} \\
(0.018)\end{array}$ \\
\hline Export Share 2000 & $\begin{array}{l}-0.023 \\
(0.037)\end{array}$ & $\begin{array}{c}0.189^{* * *} \\
(0.045)\end{array}$ & $\begin{array}{l}-2.683 \\
(8.488)\end{array}$ & $\begin{array}{c}0.031 \\
(0.044)\end{array}$ & $\begin{array}{l}-0.040 \\
(0.040)\end{array}$ \\
\hline Public R\&D Support & $\begin{array}{c}0.020 \\
(0.018)\end{array}$ & $\begin{array}{c}0.006 \\
(0.021)\end{array}$ & $\begin{array}{l}5.934^{* *} \\
(2.475)\end{array}$ & $\begin{array}{l}0.048^{\star *} \\
(0.021)\end{array}$ & $\begin{array}{c}0.074^{\star \star *} \\
(0.019)\end{array}$ \\
\hline Co-operation (industry level) & $\begin{array}{l}-0.140 \\
(0.089)\end{array}$ & $\begin{array}{l}-0.114 \\
(0.117)\end{array}$ & $\begin{array}{l}-22.400 \\
(20.463)\end{array}$ & $\begin{array}{c}0.029 \\
(0.109)\end{array}$ & $\begin{array}{c}0.054 \\
(0.093)\end{array}$ \\
\hline Incoming Spillovers (industry level) & $\begin{array}{l}0.802^{* * *} \\
(0.139)\end{array}$ & $\begin{array}{l}-0.120 \\
(0.176)\end{array}$ & $\begin{array}{c}22.442 \\
(22.085)\end{array}$ & $\begin{array}{c}0.040 \\
(0.169)\end{array}$ & $\begin{array}{l}-0.013 \\
(0.147)\end{array}$ \\
\hline Appropriability (industry level) & $\begin{array}{c}0.014 \\
(0.176)\end{array}$ & $\begin{array}{l}1.078^{* \star \star} \\
(0.213)\end{array}$ & $\begin{array}{l}54.835^{\star *} \\
(26.033)\end{array}$ & $\begin{array}{c}0.014 \\
(0.214)\end{array}$ & $\begin{array}{l}-0.145 \\
(0.187)\end{array}$ \\
\hline Intramural R\&D budget (industry level) & $\begin{array}{l}0.001 \\
(0.001)\end{array}$ & $\begin{array}{l}-0.000 \\
(0.001)\end{array}$ & $\begin{array}{l}0.834^{*} \\
(0.484)\end{array}$ & $\begin{array}{l}-0.000 \\
(0.001)\end{array}$ & $\begin{array}{l}0.000 \\
(0.001)\end{array}$ \\
\hline Cost (industry level) & $\begin{array}{l}-0.272 \\
(0.169)\end{array}$ & $\begin{array}{l}-0.141 \\
(0.211)\end{array}$ & $\begin{array}{c}38677 \\
(35.242)\end{array}$ & $\begin{array}{l}-0.101 \\
(0.207)\end{array}$ & $\begin{array}{c}0.866^{* * *} \\
(0.184)\end{array}$ \\
\hline Risk (industry level) & $\begin{array}{c}0.172 \\
(0.186)\end{array}$ & $\begin{array}{c}0.063 \\
(0.234)\end{array}$ & $\begin{array}{c}-46362 \\
(37.932)\end{array}$ & $\begin{array}{c}0.986^{* * *} \\
(0.223)\end{array}$ & $\begin{array}{c}0.049 \\
(0.201)\end{array}$ \\
\hline Constant & $\begin{array}{l}0.234^{\star *} \\
(0.105)\end{array}$ & $\begin{array}{r}0.003 \\
(0.131) \\
\end{array}$ & $\begin{array}{c}100.621^{* *} \\
(44.498)\end{array}$ & $\begin{array}{c}0.429^{* * *} \\
(0.135) \\
\end{array}$ & $\begin{array}{c}0.453^{\star \star \star} \\
(0.115) \\
\end{array}$ \\
\hline $\begin{array}{l}\text { Observations } \\
\text { R-squared }\end{array}$ & $\begin{array}{c}1,016 \\
0.08\end{array}$ & $\begin{array}{c}1,016 \\
0.17\end{array}$ & $\begin{array}{c}1,016 \\
0.24\end{array}$ & $\begin{array}{c}1,016 \\
0.12\end{array}$ & $\begin{array}{l}1,016 \\
0.16\end{array}$ \\
\hline
\end{tabular}

